\title{
Crosstalk between Stem and Progenitor Cellular Mediators with Special Emphasis on Vasculogenesis
}

\author{
Rokhsareh Rohban ${ }^{a, b} \quad$ Barbara Prietl ${ }^{a, c}$ Thomas R. Pieber ${ }^{a, c, d}$ \\ a Department of Internal Medicine, Division of Endocrinology and Diabetology, Medical University of Graz, Graz, Austria; \\ ${ }^{b}$ Center for Medical Research (ZMF), Medical University of Graz, Graz, Austria; \\ ${ }^{c}$ Competence Center for Biomarker Research in Medicine, CBmed, Graz, Austria; \\ dHEALTH-Institute for Biomedicine and Health Sciences, Joanneum Research Forschungsgesellschaft m.b.H, Graz, Austria
}

\section{Keywords}

Hematopoietic stem cells · Stem cells · Transplantation . Endothelial progenitors · Signaling · Crosstalk .

Vasculogenesis · Regeneration · Therapy

\section{Summary}

The cellular components and molecular processes of signaling during vasculogenesis have been investigated for decades. Considerable efforts have been made to unravel regulatory mechanisms of vasculogenesis through crosstalk between vasculogenic playmakers located in the vascular niche, namely hematopoietic stem cells, endothelial progenitor cells, and mesenchymal stem and progenitor cells. Recent studies have increased the knowledge about signaling events within vascular microenvironment that leads to vasculogenesis. Findings from these recent studies indicate the impact of cellular crosstalk through signaling pathways such as vascular endothelial growth factor signaling, wingless and Notch signaling in vasculogenesis and vascular development. In this review, we highlight the signaling signature between stem and progenitor cellular mediators during vasculogenesis. We further focus on hematopoietic stem cell-endothelial progenitor cell crosstalk during vasculogenesis and discuss their potential implications and benefits for therapeutic interventions and regenerative therapy.

(C) 2017 S. Karger GmbH, Freiburg

\section{Introduction}

Vasculogenesis is an essential step which takes place in course of organ regeneration, wound healing, inflammation as well as tumor growth [1-3]. It consists of migration and replication of endothelial progenitor cells (EPCs) or endothelial colony forming cells (ECFCs) as the backbone of newly formed vessels [1-3] and mesenchymal stem and progenitor cells (MSPCs) as pericytes which serve as vessel supporters and maintain microvessel stability [4-7].

EPCs and hematopoietic stem cells (HSCs) derived from adult tissues such as bone marrow (BM) have been shown to contribute to vasculogenesis during embryonic and postnatal physiological processes [8]. Recent preclinical and clinical studies have indicated that introduction of BM-derived endothelial and hematopoietic progenitors can restore tissue vascularization after ischemic events in several organs and tissues such as limb, ophthalmic retina, and myocardium. Studies have shown that HSCs are able to deliver specific vasculogenic factors that facilitate contribution of EPCs into newly forming vessels [8]. Identification of cellular crosstalk and signaling mediators that facilitate cellular communication in course of vasculogenesis leads to novel research paths to promote tissue/organ vasculogenesis and regeneration. In addition, identification of signaling factors involved in vasculogenesis leads to development of a platform for drug discovery for small molecules that accelerate vasculogenesis in regenerated tissues/organs while decelerate and/or block vasculogenesis in course of medical interventions such as cancer therapy.

Numerous clinical studies are currently ongoing that aim to identify various aspects of endothelial progenitor cell application in terms of efficacy and safety. Table 1 indicates a number of clinical trials using stem and progenitor cells for various therapeutic and regenerative interventions.

\section{KARGER}

() 2017 S. Karger GmbH, Freiburg

Fax +497614520714
Rokhsareh Rohban, $\mathrm{PhD}$

Department of Internal Medicine, Division of Endocrinology and Diabetology Medical University of Graz

Auenbruggerplatz 15, $8036 \mathrm{Graz}$, Austria

rokhsaren.rohban@medunigraz.at 
Table 1. A selection of registered clinical trials on the basis of stem and progenitor cellular mediators as the relevant therapeutic tool ( $w w w . c l i n i c a l t r i a l s . g o v)$

\begin{tabular}{|c|c|c|c|c|c|c|}
\hline & Title & Recruitment & Conditions & Phases & Intervention & Sponsors \\
\hline 1 & $\begin{array}{l}\text { Stem Cell Therapy for Vasculogen- } \\
\text { esis in Patients with Severe } \\
\text { Myocardial Ischemia }\end{array}$ & completed & $\begin{array}{l}\text { myocardial ischemia; } \\
\text { coronary heart disease }\end{array}$ & $\begin{array}{l}\text { phase I } \\
\text { phase II }\end{array}$ & $\begin{array}{l}\text { CD90+ CD105+ } \\
\text { mesenchymal stem cells }\end{array}$ & $\begin{array}{l}\text { Rigshospitalet, } \\
\text { Denmark }\end{array}$ \\
\hline 2 & $\begin{array}{l}\text { Evaluate Safety and Efficacy of } \\
\text { Autologous Bone Marrow-Derived } \\
\text { Endothelial Progenitor cells in } \\
\text { Advanced Liver Cirrhosis }\end{array}$ & completed & liver cirrhosis & $\begin{array}{l}\text { phase I } \\
\text { phase II }\end{array}$ & $\begin{array}{l}\text { intraarterial administration } \\
\text { (hepatic artery) of } \\
\text { autologous bone marrow- } \\
\text { derived endothelial } \\
\text { progenitor cells }\end{array}$ & $\begin{array}{l}\text { Clinica Universidad de } \\
\text { Navarra, Universidad } \\
\text { de Navarra, Spain }\end{array}$ \\
\hline 3 & $\begin{array}{l}\text { Autologous Endothelial } \\
\text { Progenitor Cells Transplantation } \\
\text { for Chronic Ischemic Stroke }\end{array}$ & recruiting & stroke & $\begin{array}{l}\text { phase I } \\
\text { phase II }\end{array}$ & $\begin{array}{l}\text { intravenous injection of } \\
\text { autologous endothelial } \\
\text { progenitor cells }\end{array}$ & $\begin{array}{l}\text { Southern Medical } \\
\text { University, China }\end{array}$ \\
\hline 4 & $\begin{array}{l}\text { Safety and Efficacy of Autologous } \\
\text { Endothelial Progenitor Cell CD } 133 \\
\text { for Therapeutic } \\
\text { Angiogenesis (PROGENITOR) }\end{array}$ & completed & $\begin{array}{l}\text { coronary artery disease } \\
\text { refractory angina }\end{array}$ & $\begin{array}{l}\text { phase I } \\
\text { phase II }\end{array}$ & selected CD133+ cells & $\begin{array}{l}\text { Hospital Clinico San } \\
\text { Carlos, Madrid, Spain }\end{array}$ \\
\hline 5 & $\begin{array}{l}\text { Autologous Endothelial } \\
\text { Progenitor Cells (EPCs) from } \\
\text { Peripheral Blood in the Treatment } \\
\text { of Critical Limb Ischemia }\end{array}$ & completed & critical limb ischemia & $\begin{array}{l}\text { phase I } \\
\text { phase II }\end{array}$ & $\begin{array}{l}\text { autologous } \\
\text { immunomagnetically } \\
\text { selected CD133+ } \\
\text { stem cells via intramuscular } \\
\text { implantation }\end{array}$ & $\begin{array}{l}\text { Fondazione IRCCS } \\
\text { Policlinico San Matteo, } \\
\text { Pavia, Italy }\end{array}$ \\
\hline 6 & $\begin{array}{l}\text { The Enhanced Angiogenic Cell } \\
\text { Therapy - Acute Myocardial } \\
\text { Infarction Trial (ENACT-AMI) }\end{array}$ & recruiting & $\begin{array}{l}\text { anterior wall } \\
\text { myocardial infarction }\end{array}$ & phase II & $\begin{array}{l}\text { plasma-Lyte A and } 25 \% \\
\text { autologous plasma; } \\
\text { autologous EPCs; } \\
\text { autologous EPCs transfected } \\
\text { with human eNOS }\end{array}$ & $\begin{array}{l}\text { Ottawa Hospital } \\
\text { Research Institute } \\
\text { Canada }\end{array}$ \\
\hline
\end{tabular}

\section{Stem Cells as Leading Quarterbacks in Vasculogenesis}

$\mathrm{BM}$ aspirate is rich in hematopoietic and non-hematopoietic stem cells, such as EPCs derived from embryonic hemangioblasts and MSPCs. In addition to BM, other tissue sources such as adipose tissue, placenta, and umbilical cord (Warton's jelly) etc. contain MSPC populations [9]. MSPCs have been shown to support HSC function and recovery $[10,11]$ and participate in hematopoiesis orBM regeneration $[12,13]$. Moreover, MSPCs have the potential to give rise to 'pericytes', the perivascular cells on the outer layer of vessels supporting the stability of capillaries and directing the blood flow [14]. HSCs derived from BM and circulating EPCs have been shown to play a crucial role in vasculogenesis in the course of tissue regeneration and to rehabilitate the immune system upon transplantation. This indicates the importance of BM cellular components as a source of adult stem cells for developing therapeutic and regenerative strategies [15].

HSCs were first isolated from bone marrow [16]. All hematopoietic cell lineages, including leukocytes, erythrocytes and thrombocytes, can be derived from HSCs in the BM niche. These tissue-specific stem cells [17] could divide asymmetrically and, thus, possess the capability of self-renewal and maintaining their immature, stemness status [17].
Phenotypic characterization of undifferentiated human HSCs shows diversity in CD34 [18, 19], CD38, and Kit expression but positive expression signal for Thy-1 CD90 [20], CD133, and vascular endothelial growth factor receptor-2 (VEGFR-2) [21, 22]. However, as these surface markers are not exclusively expressed on HSCs, characterization of these cells requires multi-marker assessment.

Quiescent HSCs home into either the endosteal bone to be in a close interaction with osteoblasts and supporting cells (e.g. MSPCs) and participate in various cellular interactions such as adhesion and migration, or they home into BM microvasculature sinuses to interact with endothelial cells [22-24]. A various number of cytokines and growth factors regulate the stemness or commitment state of BM-derived HSCs and their ability to migrate from endosteal bone to the vascular surface. That facilitates their segregation into the BM vasculature, and consequently, into the peripheral blood under specific physiological alerts and injuries [22, 25-27].

However, as indicated by a previous study in mouse models, only a few number of HSCs will survive to maintain the BM niche and substitute the damaged cells/tissues due to their short life-time in peripheral blood [28]. It has been shown that HSCs can also reside in the human sinusoidal endothelium, in the spleen as well as in the skin, gastrointestinal tube, neural tissue, lung and liver [23, $25,27]$. This and a previous finding of the presence of a BM-derived chemokine receptor type $4+($ CXCR 4$)+$ subpopulation of 
stem cells that express specific markers for non-hematopoietic, non-quiescent stem cells lead us to speculate that HSCs might be able to substitute the damaged cells and participate in the 'repair process' by differentiating into functional cells [29]. However, hematopoietic plasticity still remains a matter of debate, and contradictory reports argue for and against the ability of HSCs to differentiate into non-hematopoietic cell lineages [30-35].

Multi-potent EPCs and MSPCs are localized in BM stroma as well as in vascular inner and outer layers and perivascular niches, and are capable of forming mature endothelial cells and mesenchymal cell lineages such as osteoblasts, chondrocytes, adipocytes, and myoblasts $[21,25,36]$. EPCs derived from BM, inner vascular wall, umbilical cord, and umbilical cord blood as well as circulating EPCs are of great importance for clinical studies as well as for cell therapy procedures. Being capable of migrating through the circulation and differentiating into committed endothelial cells, EPCs are crucial mediators promoting vasculogenesis as well as endothelium repair in case of vascular damage [37-40]. It has been previously revealed that platelet-derived stromal cell-derived factor-1 (SDF-1) can be secreted by activated platelets and can recruit BMderived-EPCs to arterial structures in vivo [41, 42]. This indicates that EPCs could have the potential to participate in vascular repair of damaged peripheral tissues. As indicated in a previous study, isolation and transplantation of a human EPC subpopulation (CD34- and CD14- as well as CD133+ and VEGFR-2+) in nude mice with damaged artery resulted in a repaired endothelial layer and wound healing caused by the injected EPC subpopulation [38].

MSPCs have been isolated and purified from BM where they contribute with HSCs to form the niche, and also from other tissues [43], e.g., umbilical cord [44-49] and umbilical cord blood [4, 48-52], white adipose tissue [49,53-55], placenta [56], and the amniotic membrane $[43,48,49,57]$, to be used for vasculogenic processes in vitro and in vivo.

MSPCs can differentiate into pericytes [58, 59] wrapping around blood vessels in order to support their structure and provide stability $[14,43,48]$. MSPCs home to the outer wall of the microvessels and arteries in many organs, including spleen, liver, kidney, lung, pancreas, and brain $[40,60]$.

Vasculogenesis causes formation of new vessels that may occur during growth or tissue injuries to regenerate vascular structures. Re-vascularization of damaged tissues is crucial to restore tissue function for the healing process, and it requires recruitment of endothelial cells. Vasculogenesis happens through migration, proliferation, and differentiation of endothelial progenitors to form new vessels followed by stabilizing and vascular maturation steps. Endothelial progenitors have already been isolated and characterized using different methods and various tissues such as BM, umbilical cord blood, white adipose tissue etc. [61, 62]. The potential of tissue-specific endothelial colony forming progenitor cells in contributing to vasculogenesis has been identified in a number of studies $[48,63,64]$.

It has been demonstrated that EPCs which contribute to the circulating cellular compartment can be isolated from peripheral blood and can be used for re-vascularization models. It has also been shown that human peripheral CD34+ mononuclear cells can be cultured on fibronectin-coated surface ex vivo to achieve nonadherent, spindle-shaped EPCs. These cells have been further characterized by the surface expression of typical endothelial cell markers such as CD34, CD31, VEGFR-2, and Tie-2, but also CD14, CD45, and CD115 which are known hematopoietic cell markers. Asahara et al. demonstrated that application of CD34 positive blood cells to ischemia mouse models resulted in a major contribution of these cells towards vascular regeneration [65].

Endothelial colony forming cells (ECFC) are a group of progenitor cells that have been isolated from different sources such as human peripheral and umbilical cord blood samples [61, 66]. These cells have been shown to give rise to a highly proliferative, genomically stable endothelial progenitor cell population with specific surface marker profiles. ECFC has also shown a robust potential for vasculogenesis in vivo as well as endothelial network formation in vitro [67]. In a recent study, subcutaneous co-transplantation of ECFC and MSPC in immune deficient mice resulted in establishment of perfused microvessels two weeks after transplantation. The microvessels remained stable and functional even after 6 months in vivo [48].

\section{Cellular Crosstalk during Vasculogenesis}

Molecular mediators governing vasculogenesis and vascular maturation can be grouped into three categories:

1) molecules that mediate mural-endothelial and endothelial-endothelial cell interactions;

2) molecules involved in cell-matrix interactions, and

3) molecules involved in signaling pathways.

\section{Category I; Molecules that Mediate Mural-Endothelial and}

\section{Endothelial-Endothelial Cell Interactions}

Endothelial cells are inter-connected with other endothelial cells through functional proteins such as vascular endothelial (VE) cadherins and claudins.

VE-cadherin is an important mediator for endothelial-endothelial cell junctions, whereas neural cadherin ( $\mathrm{N}$-cadherin) mostly mediates the EC-mural cell junction in the process of vasculogenesis [68]. The cellular communication between supporting stromal cells can also be promoted through $\mathrm{N}$-cadherin molecules. The gap junction components, connexins (Cx37, $\mathrm{Cx} 40$ and $\mathrm{Cx} 43)$, promote communication between endothelial cells and perivascular cells. Furthermore, the endothelial/leukocyte surface marker CD31 has been shown to provide permeability to endothelial-endothelial cell junctions [69]. Tight junction molecules such as occludin, claudin, zonula occludens molecules (ZO-1, 2, 3) and the endothelial surface molecule CD148 are responsible for forming tight junctions in the blood brain barrier (BBB) and retinal microvessels in order to regulate endothelial-mural cell interaction in these sites.

It has been shown that mechanical forces during growth and expansion of the vascular network serve as a stimulator to many of the cellular and molecular interactions in the process of vasculo- 
genesis and vascular maturation [70]. However, a limited number of studies are available that discuss the mechanical parameters that regulate the cellular junctions resulting in concise vasculogenesis pattern.

\section{Category II; Molecules Involved in Cell-Matrix Interactions}

The extracellular matrix serves as a pool enriched for different growth factors and enzymes contributing to vasculogenesis. Studies on integrins have provided information about the effect of various extracellular matrix components on the survival and migration of endothelial cells. It has been previously shown that the receptor $\alpha 5 \beta 1$ fibronectin, collagen I and collagen receptors $\alpha 1 \beta 1$ and $\alpha 2 \beta 1$ are involved in promoting vasculogenesis and inhibiting endothelial cell apoptosis, whereas thrombospondin 1 and 2 (Tsp1 and Tsp2) have been shown to block vasculogenesis through integrins and proteases [71]. Paradoxically, some studies reported that suppressing the genes encoding integrin $\alpha v \beta 3$ and integrin $\alpha v \beta 5$ (integrins binding fibronectin, fibrinogen, endostatin and von Willebrand factor) does not inhibit vasculogenesis [72, 73].

On the other hand, proteases released from endothelial and mural cells can cleave the matrix and plasma proteins into components that mediate endothelial cell apoptosis (e.g. angiostatin that results from plasminogen cleavage) whereas protease inhibitors in the matrix sustain vascular stability [70]. Further studies are required to unravel the precise role of cell-matrix interactions in vasculogenesis and vascular stability processes.

\section{Category III; Molecules Involved in Signaling Pathways}

Cellular activities are governed by a series of molecular events resulting in cellular crosstalk. This regulatory cell signaling implicates protein-protein interactions as the major cell process regulators as well as cell-microenvironment interactions which are necessary for differentiation, tissue homeostasis and repair [74, 75]. Aberrant cell signaling could result in cell malfunction or diseases such as cancer and diabetes [74].

Although cell signaling has been studied intensively within the single cell types, it may also happen between two different cell types e.g. when the surface embryonic cells are being attached and the embryo is implanted to the endometrial tissue. This process is known to be mediated by $\beta$-catenin signaling molecule in the process of Wingless (WNT) signaling [76].

Cellular components that are involved in vasculogenesis are dependent on a potent, well-orchestrated and regulated system of cellular crosstalk catalyzed by different classes of signaling molecules. Several signaling pathways have been identified to regulate endothelial progenitor-mesenchymal stem and progenitor crosstalk during vasculogenesis such as calcium calmodulin and focal adhesion protein kinase signaling pathway [48] whereas other signaling events have been studied through which hematopoietic stem and endothelial progenitor cells communicate within the vascular microenvironment e.g. SDF-1 (CXCL12)/CXCR4 signaling [77-80], vascular endothelial growth factor signaling (VEGF) [81-84], Tie2/ Ang-1 signaling [85, 86] , hedgehog [87-89] and Notch signaling [90, 91], as well as Wingless (Wnt) signaling [92-95].
The following subchapters reflect the most important communication paths between hematopoietic stem cells and endothelial progenitor cells as effective cellular crosstalks during vasculogenesis:

\section{SDF-1-CXCR4 Signaling Pathway}

Studies have revealed that the SDF-1 (also known as CXCL12) has a crucial impact on recruitment of CXCR4+ BM cells to vascular microenvironment, resulting in revascularization of injured tissues and tumor growth $[77,78]$. The precise mechanism by which activation of CXCR4 modulates vasculogenesis has not been unraveled yet. SDF-1 has been also shown to promote mobilization of pro-vasculogenic CXCR4+ VEGFR-1+ hematopoietic cells, thereby supports revascularization of injured and ischemic organs [78]. During migration, HSCs have been found to express CXCR4, the receptor for the chemokine SDF-1, and integrin $\alpha 4 \beta 1$. In BM stromal microenvironment, osteoblasts and endothelial cells release SDF-1 while CXCR4 is expressed by hematopoietic progenitor cells, thus supporting successful BM engraftment in vivo [79, 80].

\section{VEGF Signaling}

VEGF family mediators like VEGF-A play an important role not only during initiation of vasculogenesis through VEGFR-2 (FLK-1), but also during vessel maturation that ultimately results in establishment of arteries (arteriogenesis) [81, 82]. Neurophilins (NRP1 and NRP2) serve as independent VEGF receptors that increase VEGFR-2 activity. VEGFR-2 deficiency and severe decrease in VEGF expression hampers vascular development [96]. Mutations and polymorphism in the gene encoding VEGFR-2 result in vascular tumor formation as well as in abnormal and/or pathological vasculogenesis patterns [97].

In perfused vessels, an endothelial tip cell is activated by VEGFC, a ligand for VEGFR-2 and VEGFR-3, to direct the vessel growth in the presence of VEGF receptors and Notch ligands like DLL4 and JAGGED1. Upregulation of DLL4 and activation of Notch signaling in stalk cells result in VEGFR-2 downregulation and cause the stalk cell to be less responsive to VEGF, thus ensuring a guiding role for the tip cell in the process of vascular development $[83,84]$. Paracrine VEGF secreted from cancer cells, myeloid cells, or pericytes promotes vascular branching, whereas vasculature homeostasis is sustained by autocrine VEGF secretion $[98,99]$.

VEGFR-3 signaling plays a crucial role in prenatal venous-derived vasculogenesis as well as in lymphatic vessel remodeling from the pre-existing ones. A study in zebrafish revealed that the vessel formation through sprouting of venous endothelial cells is prohibited by VEGF-2, whereas VEGF-3 facilitates the sprouting of the venous-fated endothelial cells resulting in vein development [100].

VEGF-B is another member of VEGF family that shows vasculogenic potential only in some particular tissues like heart tissue, facilitating cardiac vascular development without additional effects on permeability of the vessels [101].

VEGFR-1 - also known as FLT-1 - possesses weak tyrosine kinase activity but can trap extra amounts of free VEGF to maintain VEGFR-2 activity to a normal state. VEGFR-1 blockade and/or deficiency lead to vessel overgrowth [102]. In contrast, the endothe- 
lial and stromal VEGFR-1 signaling cascade has been shown to promote pathological vasculogenesis by providing a higher growth rate for VEGFR-1+ cancer cells and by increasing matrix metalloproteinase 9 expression in endothelial cells at metastatic state [103].

It has been indicated that the loss of a single VEGF allele in mice leads to severe vascular impairment and mortality before HSC specification [104]. Other studies have revealed that VEGF-A is crucial for HSC formation: longer VEGF-A isoforms are essential for HSC specification [105]. Also, VEGF signaling has been shown to have crucial impact in formation of HSCs from endothelial precursors [105].

\section{Notch Signaling}

The Notch signaling pathway is required for determining the arterial program of both endothelial and smooth muscle cells; however, it is simultaneously involved in the generation of HSCs, which will give rise to hematopoietic cells. Notch signaling also regulates the function of EPCs, which are BM-derived cells able to differentiate into endothelial cells which could be considered the adult correlate of the angioblast. In addition, Notch signaling has been reported to control sprouting angiogenesis during blood vessels formation in adults [106].

Notch signaling is involved in cell fate decisions during murine vascular development and hematopoiesis in BM microenvironment. In order to elucidate the relation between HSCs and human EPCs in the BM niche, impact of Notch signals (Jagged-1 and delta-like ligand 1 (Dll-1)) on proliferation and differentiation of human CD133+ EPCs needs to be studied [106].

To investigate the vasculogenic properties of human Jagged-1and human Dll-1-stimulated EPC in vivo, these cells were transplanted into the ischemic limb of nude mouse. The result indicated that transplantation of EPCs stimulated by human Jagged-1, but not human Dll-1, elevated density of microvessels in ischemic limb muscles, suggesting that human Notch signaling affects EPC proliferation and differentiation in the BM niche. Human Jagged-1 has been shown to induce proliferation and differentiation of CD133+ cord blood progenitor cells compared to human Dll-1; therefore, human Jagged-1 signaling in the BM microenvironment can be used to expand EPCs for therapeutic and regenerative vasculogenic interventions. Moreover, it has been revealed recently that Jagged-1 signaling in the BM microenvironment supports proliferation and expansion of EPCs [107] and promotes commitment of CD133+ human umbilical cord blood cells during vasculogenesis [107].

It has been illustrated in the vessel branching model that the tip cells of the vessel migrate while stalk cells proliferate. This might be a result of Notch signaling in this model [83]. VEGFR-2 is activated in response to VEGF and cause expression of DLL4 in the tip cells. Consequently, DLL4 activates Notch in the stalk cells that suppresses VEGFR-2 while upregulates VEGFR-1, resulting in less sprouting and branching but more vessel formation [83]. JAGGED1 is another Notch ligand that is mainly expressed by stalk cells and contributes to DLL4 in order to select the tip cell [108].
However, as Notch signaling itself activates its inhibitor Notchregulated ankyrin protein over time, this signaling cascade varies in the vascular microenvironment [109].

Notch signaling mediators play an important role in the development of arterio-venous and venous endothelial structure in the establishing vessel $[90,110]$. In endothelial cells, activation of Notch signaling leads to induction of many arterial markers including ephrin B2 and CD44, and suppression of venous markers such as ephrin type B receptor $4[90,91]$.

\section{Hedgehog Signaling}

Signaling by the hedgehog (hh) family molecules, including sonic hedgehog (shh) and Indian hedgehog (ihh), have a regulatory role in Notch expression, thus contributing to vascular structure and arterial formation in the embryo [111]. It has been revealed that hh signaling is genetically upstream of VEGF cascade, which governs Notch activation in the endothelium [89]. It can be concluded that hh signaling is a key regulator of a crucial crosstalk which governs accurate pattern of vascular formation and endothelium generation $[89,105]$. A study aiming to investigate the impact of shh expression in vasculogenesis in the course of myocardial injury revealed that upon application of shh, vasculogenic components such as VEGF and fibroblast growth factor were significantly upregulated [87]. This study suggests that the elevated level of shh through activation of hh signaling pathway may play a crucial role in the process of vessel formation [87].

Williams et al. [88] have also shown that arterial endothelial cell formation is induced by hh signaling through repressing venous cell fate in zebrafish models. They reported that upregulation of hh signaling elevates arterial cellular population while hampers venous cell fate during vasculogenesis. These evidences, together with several reports on the role of hh signaling in vascularity of tumors such as breast cancerous tumors [112], unravel the involvement of hh signaling in vascular formation and development.

\section{Wnt Signaling}

Wnt signaling has been shown to govern specification and homeostasis of several tissues. Wnt signaling pathway consists of 19 ligands that associate with frizzled (FZD) receptors on the surface of several cell types $[113,114]$. When there is no ligand binding, $\beta$-catenin is degraded [115]. However, activation of Wnt receptors through induction of the ligand blocks $\beta$-catenin degradation, thus allowing for translocation of this molecule to the nucleus and activation of target gene transcription [116]. It has been revealed that $\beta$-catenin deletion in the endothelium results in hematopoietic deficiencies [105]. These findings indicate that Wnt signaling plays crucial role in HSC and artery fate.

It has also been illustrated that endothelial cells express Wnt ligands and their FZD receptor that control endothelial cell proliferation. As the vessel branching takes place, Wnt signaling is activated by Notch in stalk cells [109]. Suppression of some of Wnt and FZD genes (Wnt2, Wnt5a, FZD4, and FZD5) in mouse resulted in defective vascular structures. Inactivation of WNT7a and WNT7b has been shown to result in an impairedBBB vessel formation [117]. 
Table 2. A number of clinical and pre-clinical studies using small molecule signaling mediator inhibitors as related interventions ( $w w w . c l i n i c a l t r i a l s . g o v)$

\begin{tabular}{|c|c|c|c|}
\hline & Study & Small molecule/drug involved in the study & Disease/Condition \\
\hline 1 & $\begin{array}{l}\text { Profile of Soluble and Cellular } \\
\text { Biomarkers and of Functional Imaging during } \\
\text { Antiangiogenic Therapies in Cancer Patients }\end{array}$ & $\begin{array}{l}\text { avastin, suntent, and nexavar; kinase inhibitors, } \\
\text { VEGF signaling inhibitors }\end{array}$ & $\begin{array}{l}\text { hepatocellular cancer } \\
\text { non-small cell lung cancer } \\
\text { renal cell cancer } \\
\text { colorectal cancer }\end{array}$ \\
\hline 2 & $\begin{array}{l}\text { ME-344 in Early HER2-negative Breast Cancer } \\
\text { with Antiangiogenic-INDUCED Mitochondrial } \\
\text { Metabolism }\end{array}$ & $\begin{array}{l}\text { ME-344, a small molecule mitochondrial inhibitor } \\
\text { Bevacizumab, a recombinant humanized monoclonal } \\
\text { antibody that blocks angiogenesis by inhibiting } \\
\text { vascular endothelial growth factor A (VEGF-A) }\end{array}$ & $\begin{array}{l}\text { breast cancer } \\
\text { human epidermal growth factor } 2 \\
\text { negative carcinoma of breast } \\
\text { early-stage breast carcinoma }\end{array}$ \\
\hline 3 & $\begin{array}{l}\text { A Dose Finding Study Followed by a Safety and } \\
\text { Efficacy Study in Patients with Advanced Solid } \\
\text { Tumors or Multiple Myeloma With FGF/FGFR- } \\
\text { Related Abnormalities }\end{array}$ & $\begin{array}{l}\text { TAS-120, a novel, highly potent and selective } \\
\text { small molecule fibroblast growth factor receptor } \\
\text { inhibitor }\end{array}$ & $\begin{array}{l}\text { solid tumors } \\
\text { multiple myeloma }\end{array}$ \\
\hline 4 & $\begin{array}{l}\text { MK2206 in Treating Younger Patients With } \\
\text { Recurrent or Refractory Solid Tumors or Leukemia }\end{array}$ & MK2206, a protein B kinase Akt inhibitor & $\begin{array}{l}\text { accelerated phase chronic } \\
\text { myelogenous leukemia }\end{array}$ \\
\hline
\end{tabular}

Table 3. Vasculogenesis mediators, molecules involved and their role in course of vasculogenesis

\begin{tabular}{lll}
\hline Vasculogensis mediators & Molecules invloved & Role \\
\hline I) Cell-cell mediators & $\begin{array}{l}\text { VE-cadherin } \\
\text { N-cadherin } \\
\text { claudin } \\
\text { connexins }(\mathrm{Cx} 37, \mathrm{Cx} 40 \text {, and CX43) } \\
\text { occludin } \\
\text { zonula occludens molecules (ZO-1, ZO-2, ZO-3) }\end{array}$ & cellular communication \\
& $\begin{array}{l}\text { integrins ( } \alpha v \beta 3, a v \beta 5, a 4 \beta 1) \\
\text { thrombospondin 1 and 2 (Tsp1 and Tsp2) }\end{array}$ & $\begin{array}{l}\text { cell survical } \\
\text { cell migration } \\
\text { apoptosis inhibition } \\
\text { promoting vasculogenesis (integrins) } \\
\text { blocking vasculogenesis (Tsp) }\end{array}$ \\
\hline II) Cell-matrix mediators & & $\begin{array}{l}\text { promoting and supporting vasculogenesis } \\
\text { cellular regulation } \\
\text { cellular proliferation and differentiation } \\
\text { cellular fate determination }\end{array}$ \\
\hline III) Signaling mediators & $\begin{array}{l}\text { SDF-1 (CXCL12)/CXCR4 signaling } \\
\text { vascular endothelial growth factor signaling (VEGF) } \\
\text { Tie2/Ang1 signaling } \\
\text { hedgehog } \\
\text { Notch signaling } \\
\text { wingless (Wnt)/ } \beta \text {-cadherine signaling }\end{array}$ & \\
\hline & & \\
\hline
\end{tabular}

\section{Identification of Cellular Crosstalk during Vasculogenesis: Potential Benefits for Regeneration and Therapy}

Unraveling cellular crosstalk that occurs during vasculogenesis through methods such as high-throughput screening data analysis and proteomics microarray analysis could provide a library of potential targets that can be used for therapeutic and regenerative interventions pro and against vasculogenesis. This ultimately leads to establishment of novel effective therapeutic and regenerative strategies.

Signaling mediators can be used as vasculogenic inducers to promote vasculogenesis during organ and tissue regeneration and repair [118] as well as during the development of vascular graft [119]. For instance, it has been indicated that activation of the SDF-1-CXCR4 signaling pathway promotes recruitment of the pro-angiogenic cells from $\mathrm{BM}$ and other tissues, leading to vasculogenesis [78].
On the other hand, many anti-angiogenic therapies are based on the blockade of signaling molecules that are known to govern vasculogenesis such as the VEGF signaling pathway and related components. It has been indicated that several VEGF-targeted drugs, administered either as single medication or combined with chemotherapy, have positive effects on impairing vasculogenesis in cancerous tumors [120]. To date, several small molecules have been identified that can serve as inducers and/or inhibitors of targeted signaling molecules. These small molecules have been used in numerous preclinical and clinical studies that either aim to promote vasculogenesis or abolish it. In regenerative therapy, vasculogenesis is often favored, whereas vasculogenesis has to be blocked when it comes to cancer/tumor therapy. Table 2 illustrates a selection of small molecules that have been used at the preclinical and clinical level. Table 3 summarizes cellular crosstalk category (I-III) that has been indicated in section 3 . 


\section{Conclusion}

Vasculogenesis is an essential step which takes place in course of organ regeneration, wound healing, inflammation, and tumor growth [1-3]. Vessel formation consists of migration and replication of endothelial progenitors to form the backbone of newly formed vessel [1-3] and MSPCs such as pericytes which serve as vessel supporters and maintain microvessel stability [4-7]. MSPCs, endothelial progenitor cells and hematopoietic stem cells interact in the vascular microenvironment through signaling mediators to accomplish vessel formation.

Cellular crosstalk takes place mostly through signaling pathways such as Wnt, Notch, hh, VEGF and SDF-1-CXCR4 signaling. The signaling mediators can be further evaluated and used for regeneration and therapy.

\section{Acknowledgements}

The authors thank Beate Boulgaropoulos, PhD (Department of Internal Medicine, Division of Endocrinology and Diabetology, Medical University of Graz, Austria and HEALTH - Institute for Biomedicine and Health Sciences, Joanneum Research GmbH, Graz, Austria) for critical review and editorial assistance with the manuscript.

\section{Disclosure Statement}

The authors declare that they have no competing interests.

\section{References}

1 Segura I, Serrano A, De Buitrago GG, Gonzalez MA, Abad JL, et al: Inhibition of programmed cell death impairs in vitro vascular-like structure formation and reduces in vivo angiogenesis. FASEB J 2002;16:833-841.

2 Elmore S: Apoptosis: a review of programmed cell death. Toxicol Pathol 2007;35:495-516.

3 Krysko DV, Vandenabeele P: From regulation of dying cell engulfment to development of anti-cancer therapy. Cell Death Differ 2008;15:29-38.

4 Reinisch A, Bartmann C, Rohde E, Schallmoser K, Bjelic-Radisic V, et al: Humanized system to propagate cord blood-derived multipotent mesenchymal stromal cells for clinical application. Regen Med 2007;2:371-382.

5 Schallmoser K, Bartmann C, Rohde E, Reinisch A Kashofer K, et al: Human platelet lysate can replace fetal bovine serum for clinical-scale expansion of functional mesenchymal stromal cells. Transfusion 2007; 47:1436-1446.

6 Reinisch A, Hofmann NA, Obenauf AC, Kashofer K, Rohde E, et al: Humanized large-scale expanded endothelial colony-forming cells function in vitro and in vivo. Blood 2009;113:6716-6725.

7 Hofmann NA, Reinisch A, Strunk D: Endothelial colony-forming progenitor cell isolation and expansion. Methods Mol Biol 2012;879:381-387.

8 Rafii S, Lyden D: Therapeutic stem and progenitor cell transplantation for organ vascularization and regeneration. Nat Med 2003;9:702-712.

9 Hass R, Kasper C, Bohm S, Jacobs R: Different populations and sources of human mesenchymal stem cells (MSC): a comparison of adult and neonatal tissue-derived MSC. Cell Commun Signal 2011;9:12.

10 Liang X, Su YP, Kong PY, Zeng DF, Chen XH, et al: Human bone marrow mesenchymal stem cells expressing SDF-1 promote hematopoietic stem cell function of human mobilised peripheral blood CD34+ cells in vivo and in vitro. Int J Radiat Biol 2010;86:230-237.

11 Li ZY, Wang CQ, Lu G, Pan XY, Xu KL: Effects of bone marrow mesenchymal stem cells on hematopoietic recovery and acute graft-versus-host disease in murine allogeneic umbilical cord blood transplantation model. Cell Biochem Biophys 2014;70:115-122.

12 Poon Z, Lee WC, Guan G, Nyan LM, Lim CT, et al: Bone marrow regeneration promoted by biophysically sorted osteoprogenitors from mesenchymal stromal cells. Stem Cells Transl Med 2015;4:56-65.
13 Mendez-Ferrer S, Michurina TV, Ferraro F, Mazloom AR, Macarthur BD, et al: Mesenchymal and haematopoietic stem cells form a unique bone marrow niche. Nature 2010;466:829-834.

14 Bergers G, Song S: The role of pericytes in blood-vessel formation and maintenance. Neuro Oncol 2005;7: 452-464.

15 Mimeault M, Hauke R, Batra SK: Stem cells: a revolution in therapeutics-recent advances in stem cell biology and their therapeutic applications in regenerative medicine and cancer therapies. Clin Pharmacol Ther 2007;82:252-264

16 Till JE, McCulloch EA: A direct measurement of the radiation sensitivity of normal mouse bone marrow cells. Radiat Res 1961;14:213-222.

17 Spangrude GJ, Heimfeld S, Weissman IL: Purification and characterization of mouse hematopoietic stem cells. Science 1988;241:58-62.

18 Majdic O, Stockl J, Pickl WF, Bohuslav J, Strobl H, et al: Signaling and induction of enhanced cytoadhesiveness via the hematopoietic progenitor cell surface molecule CD34. Blood 1994;83:1226-1234.

19 Civin CI, Strauss LC, Brovall C, Fackler MJ, Schwartz JF, et al: Antigenic analysis of hematopoiesis. III. A hematopoietic progenitor cell surface antigen defined by a monoclonal antibody raised against KG-1a cells. J Immunol 1984;133:157-165.

20 Murray L, Chen B, Galy A, Chen S, Tushinski R, et al: Enrichment of human hematopoietic stem cell activity in the CD34+Thy-1+Lin - subpopulation from mobilized peripheral blood. Blood 1995;85:368-378.

21 Bryder D, Rossi DJ, Weissman IL: Hematopoietic stem cells: the paradigmatic tissue-specific stem cell. Am J Pathol 2006;169:338-346.

22 Wilson A, Trumpp A: Bone-marrow haematopoieticstem-cell niches. Nat Rev Immunol 2006;6:93-106.

23 Kiel MJ, Yilmaz OH, Iwashita T, Yilmaz OH, Terhorst C, et al: SLAM family receptors distinguish hematopoietic stem and progenitor cells and reveal endothelial niches for stem cells. Cell 2005;121:1109-1121.

24 Arai F, Suda T: Maintenance of quiescent hematopoietic stem cells in the osteoblastic niche. Ann N Y Acad Sci 2007;1106:41-53.

25 Mimeault M, Batra SK: Recent advances on multiple tumorigenic cascades involved in prostatic cancer progression and targeting therapies. Carcinogenesis 2006; 27:1-22.
26 Moore KA, Lemischka IR: Stem cells and their niches. Science 2006;311:1880-1885.

27 Bhattacharya D, Rossi DJ, Bryder D, Weissman IL: Purified hematopoietic stem cell engraftment of rare niches corrects severe lymphoid deficiencies without host conditioning. J Exp Med 2006;203:73-85.

28 Wright DE, Wagers AJ, Gulati AP, Johnson FL, Weissman IL: Physiological migration of hematopoietic stem and progenitor cells. Science 2001;294:1933-1936.

29 Kucia M, Wojakowski W, Reca R, Machalinski B, Gozdzik J, et al: The migration of bone marrow-derived non-hematopoietic tissue-committed stem cells is regulated in an SDF-1-, HGF-, and LIF-dependent manner. Arch Immunol Ther Exp (Warsz) 2006;54:121-135.

30 Lagasse E, Connors H, Al-Dhalimy M, Reitsma M, Dohse M, et al: Purified hematopoietic stem cells can differentiate into hepatocytes in vivo. Nat Med 2000;6: 1229-1234.

31 Krause DS, Theise ND, Collector MI, Henegariu O, Hwang S, et al: Multi-organ, multi-lineage engraftment by a single bone marrow-derived stem cell. Cell 2001; 105:369-377.

32 Sigurjonsson OE, Perreault MC, Egeland T, Glover JC: Adult human hematopoietic stem cells produce neurons efficiently in the regenerating chicken embryo spinal cord. Proc Natl Acad Sci U S A 2005;102:5227-5232.

33 Murry CE, Soonpaa MH, Reinecke H, Nakajima H, Nakajima HO, et al: Haematopoietic stem cells do not transdifferentiate into cardiac myocytes in myocardial infarcts. Nature 2004;428:664-668.

34 Stadtfeld M, Graf T: Assessing the role of hematopoietic plasticity for endothelial and hepatocyte development by non-invasive lineage tracing. Development 2005;132:203-213.

35 Ozturk MA, Guven GS, Haznedaroglu IC: How hematopoietic stem cells know and act in cardiac microenvironment for stem cell plasticity? Impact of local reninangiotensin systems. Med Hypotheses 2004;63:866-874.

36 Ringden O: Immunotherapy by allogeneic stem cell transplantation. Adv Cancer Res 2007;97:25-60.

37 Asahara T, Kawamoto A: Endothelial progenitor cells for postnatal vasculogenesis. Am J Physiol Cell Physiol 2004;287:C572-579.

38 Friedrich EB, Walenta K, Scharlau J, Nickenig G, Werner N: CD34-/CD133+/VEGFR-2+ endothelial progenitor cell subpopulation with potent vasoregenerative capacities. Circ Res 2006;98:e20-25. 
39 Schatteman GC, Dunnwald M, Jiao C: Biology of bone marrow-derived endothelial cell precursors. Am J Physiol Heart Circ Physiol 2007;292:H1-18.

40 Zengin E, Chalajour F, Gehling UM, Ito WD, Treede $\mathrm{H}$, et al: Vascular wall resident progenitor cells: a source for postnatal vasculogenesis. Developmen 2006;133:1543-1551.

41 Massberg S, Konrad I, Schurzinger K, Lorenz M, Schneider S, et al: Platelets secrete stromal cell-derived factor 1alpha and recruit bone marrow-derived progenitor cells to arterial thrombi in vivo. J Exp Med 2006; 203:1221-1233.

42 Stellos K, Gawaz M: Platelets and stromal cell-derived factor-1 in progenitor cell recruitment. Semin Thromb Hemost 2007;33:159-164.

43 Rohban R, Pieber TR: Mesenchymal stem and progenitor cells in regeneration: tissue specificity and regenerative potential. Stem Cells Int 2017;2017:16.

44 Romanov YA, Svintsitskaya VA, Smirnov VN: Searching for alternative sources of postnatal human mesenchymal stem cells: candidate MSC-like cells from umbilical cord. Stem Cells 2003;21:105-110

45 Sarugaser R, Lickorish D, Baksh D, Hosseini MM, Davies JE: Human umbilical cord perivascular (HUCPV) cells: a source of mesenchymal progenitors. Stem Cells 2005;23:220-229.

46 Lin YM, Zhang GZ, Leng ZX, Lu ZX, Bu LS, et al: Study on the bone marrow mesenchymal stem cells induced drug resistance in the U937 cells and its mechanism. Chin Med J (Engl) 2006;119:905-910.

47 Reinisch A, Strunk D: Isolation and animal serum free expansion of human umbilical cord derived mesenchymal stromal cells (MSCs) and endothelial colony forming progenitor cells (ECFCs). J Vis Exp. 2009;(32) pii: 1525

48 Rohban R, Reinisch A, Etchart N, Schallmoser K, Hofmann NA, et al: Identification of an effective early signaling signature during neo-vasculogenesis in vivo by ex vivo proteomic profiling. PLoS One 2013;8:e66909.

49 Rohban R, Etchart N, Pieber T: Vasculogenesis potential of mesenchymal and endothelial stem cells isolated from various human tissues. bioRxiv 2016; doi: https:// doi.org/10.1101/049668.

50 Erices A, Conget P, Minguell JJ: Mesenchymal progenitor cells in human umbilical cord blood. $\mathrm{Br} \mathrm{J} \mathrm{Hae}-$ matol 2000;109:235-242.

51 Bieback K, Kern S, Kluter H, Eichler H: Critical parameters for the isolation of mesenchymal stem cells from umbilical cord blood. Stem Cells 2004;22:625-634.

52 Kogler G, Sensken S, Airey JA, Trapp T, Muschen M, et al: A new human somatic stem cell from placental cord blood with intrinsic pluripotent differentiation potential. J Exp Med 2004;200:123-135.

53 Gronthos S, Simmons PJ, Graves SE, Robey PG: Integrin-mediated interactions between human bone marrow stromal precursor cells and the extracellular matrix. Bone 2001;28:174-181.

54 Zuk PA, Zhu M, Ashjian P, De Ugarte DA, Huang JI, et al: Human adipose tissue is a source of multipotent stem cells. Mol Biol Cell 2002;13:4279-4295.

55 Kern S, Eichler H, Stoeve J, Kluter H, Bieback K: Comparative analysis of mesenchymal stem cells from bone marrow, umbilical cord blood, or adipose tissue. Stem Cells 2006;24:1294-1301.

56 Miao Z, Jin J, Chen L, Zhu J, Huang W, et al: Isolation of mesenchymal stem cells from human placenta: comparison with human bone marrow mesenchymal stem cells. Cell Biol Int 2006;30:681-687.

57 Insausti CL, Blanquer M, Bleda P, Iniesta P, Majado MJ, et al: The amniotic membrane as a source of stem cells. Histol Histopathol 2010;25:91-98.

58 Prockop DJ: Marrow stromal cells as stem cells for nonhematopoietic tissues. Science 1997;276:71-74.
59 Pittenger MF, Mackay AM, Beck SC, Jaiswal RK, Douglas R, et al: Multilineage potential of adult human mesenchymal stem cells. Science 1999;284:143-147.

60 da Silva Meirelles L, Chagastelles PC, Nardi NB: Mesenchymal stem cells reside in virtually all post-natal organs and tissues. J Cell Sci 2006;119:2204-2213.

61 Mead LE, Prater D, Yoder MC, Ingram DA: Isolation and characterization of endothelial progenitor cells from human blood. Curr Protoc Stem Cell Biol Chapter 2008;2:Unit 2C.1.

62 Javed MJ, Mead LE, Prater D, Bessler WK, Foster D, et al: Endothelial colony forming cells and mesenchymal stem cells are enriched at different gestational ages in human umbilical cord blood. Pediatr Res 2008;64:68-73.

63 Zhou L, Xia J, Qiu X, Wang P, Jia R, et al: In vitro evaluation of endothelial progenitor cells from adipose tissue as potential angiogenic cell sources for bladder angiogenesis. PLoS One 2015;10:e0117644.

64 Joo HJ, Seo HR, Jeong HE, Choi SC, Park JH, et al: Smooth muscle progenitor cells from peripheral blood promote the neovascularization of endothelial colonyforming cells. Biochem Biophys Res Commun 2014; 449:405-411.

65 Asahara T, Murohara T, Sullivan A, Silver M, van der Zee R, et al: Isolation of putative progenitor endothelial cells for angiogenesis. Science 1997;275:964-967.

66 Ingram DA, Mead LE, Tanaka H, Meade V, Fenoglio A, et al: Identification of a novel hierarchy of endothelial progenitor cells using human peripheral and umbilical cord blood. Blood 2004;104:2752-2760.

67 Rohban R, Etchart N, Pieber T: Transplantation of endothelial progenitor cells solely leads to development of functional neo-vessels in vivo. bioRxiv 2016; doi: https://doi.org/10.1101/049650.

68 Dejana E, Tournier-Lasserve E, Weinstein BM: The control of vascular integrity by endothelial cell junctions: molecular basis and pathological implications. Dev Cell 2009;16:209-221.

69 Carmeliet P, Jain RK: Molecular mechanisms and clinical applications of angiogenesis. Nature 2011;473: 298-307.

70 Jain RK: Molecular regulation of vessel maturation. Nat Med 2003;9:685-693.

71 Lawler J: The functions of thrombospondin-1 and-2. Curr Opin Cell Biol 2000;12:634-640.

72 Hynes RO: A reevaluation of integrins as regulators of angiogenesis. Nat Med 2002;8:918-921.

73 Stupack DG, Cheresh DA: Get a ligand, get a life: integrins, signaling and cell survival. J Cell Sci 2002;115: 3729-3738.

74 Kolch W, Pitt A: Functional proteomics to dissect tyrosine kinase signalling pathways in cancer. Nat Rev Cancer 2010;10:618-629.

75 Gadbois DM, Crissman HA, Tobey RA, Bradbury EM: Multiple kinase arrest points in the G1 phase of nontransformed mammalian cells are absent in transformed cells. Proc Natl Acad Sci U S A 1992;89:86268630 .

76 Mohamed OA, Jonnaert M, Labelle-Dumais C, Kuroda $\mathrm{K}$, Clarke HJ, et al: Uterine Wnt/beta-catenin signaling is required for implantation. Proc Natl Acad Sci U S A 2005;102:8579-8584.

77 Ho TK, Shiwen X, Abraham D, Tsui J, Baker D: Stromal-cell-derived factor-1 (SDF-1)/CXCL12 as potential target of therapeutic angiogenesis in critical leg ischaemia. Cardiol Res Pract 2012;2012:7.

78 Petit I, Jin D, Rafii S: The SDF-1-CXCR4 signaling pathway: a molecular hub modulating neo-angiogenesis. Trends Immunol 2007;28:299-307.

79 Burger JA, Spoo A, Dwenger A, Burger M, Behringer D: CXCR4 chemokine receptors (CD184) and alpha4betal integrins mediate spontaneous migration of human CD34+ progenitors and acute myeloid leukaemia cells beneath marrow stromal cells (pseudoemperipolesis). Br J Haematol 2003;122:579-589.
80 De Clercq E: Potential clinical applications of the CXCR4 antagonist bicyclam AMD3100. Mini Rev Med Chem 2005;5:805-824.

81 Ferrara N: VEGF-A: a critical regulator of blood vessel growth. Eur Cytokine Netw 2009;20:158-163.

82 Nagy JA, Dvorak AM, Dvorak HF: VEGF-A and the induction of pathological angiogenesis. Annu Rev Pathol 2007;2:251-275.

83 Phng LK, Gerhardt H: Angiogenesis: a team effort coordinated by notch. Dev Cell 2009;16:196-208.

84 Tvorogov D, Anisimov A, Zheng W, Leppanen VM, Tammela T, et al: Effective suppression of vascular network formation by combination of antibodies blocking VEGFR ligand binding and receptor dimerization. Cancer Cell 2010;18:630-640.

85 Maisonpierre PC, Suri C, Jones PF, Bartunkova S, Wiegand SJ, et al: Angiopoietin-2, a natural antagonist for Tie2 that disrupts in vivo angiogenesis. Science 1997;277:55-60.

86 Uemura A, Ogawa M, Hirashima M, Fujiwara T, Koyama S, et al: Recombinant angiopoietin-1 restores higher-order architecture of growing blood vessels in mice in the absence of mural cells. J Clin Invest 2002; 110:1619-1628.

87 Guo W, Yi X, Ren F, Liu L, Wu S, et al: Activation of $\mathrm{SHH}$ signaling pathway promotes vasculogenesis in post-myocardial ischemic-reperfusion injury. Int J Clin Exp Pathol 2015;8:12464-12472.

88 Williams C, Kim SH, Ni TT, Mitchell L, Ro H, et al: Hedgehog signaling induces arterial endothelial cell formation by repressing venous cell fate. Dev Biol 2010;341:196-204.

89 Lawson ND, Vogel AM, Weinstein BM: sonic hedgehog and vascular endothelial growth factor act upstream of the Notch pathway during arterial endothelial differentiation. Dev Cell 2002;3:127-136.

90 Lawson ND, Scheer N, Pham VN, Kim CH, Chitnis $\mathrm{AB}$, et al: Notch signaling is required for arterial-venous differentiation during embryonic vascular development. Development 2001;128:3675-3683.

91 Fischer A, Schumacher N, Maier M, Sendtner M, Gessler M: The Notch target genes Heyl and Hey2 are required for embryonic vascular development. Genes Dev 2004;18:901-911.

92 Gore AV, Swift MR, Cha YR, Lo B, McKinney MC, et al: Rspol/Wnt signaling promotes angiogenesis via Vegfc/Vegfr3. Development 2011;138:4875-4886.

93 Li R, Beebe T, Jen N, Yu F, Takabe W, et al: Shear stress-activated Wnt-angiopoietin-2 signaling recapitulates vascular repair in zebrafish embryos. Arterioscler Thromb Vasc Biol 2014;34:2268-2275.

94 Chen Y, Zhang Y, Deng Q, Shan N, Peng W, et al: Inhibition of Wnt inhibitory factor 1 under hypoxic condition in human umbilical vein endothelial cells promoted angiogenesis in vitro. Reprod Sci 2016;23:1348-1358.

95 Zhang Z, Nor F, Oh M, Cucco C, Shi S, et al: Wnt/ beta-catenin signaling determines the vasculogenic fate of postnatal mesenchymal stem cells. Stem Cells 2016; 34:1576-1587.

96 Carmeliet P: Angiogenesis in health and disease. Nat Med 2003;9:653-660.

97 Jain RK, Duda DG, Willett CG, Sahani DV, Zhu AX, et al: Biomarkers of response and resistance to antiangiogenic therapy. Nat Rev Clin Oncol 2009;6:327-338.

98 Stockmann C, Doedens A, Weidemann A, Zhang N, Takeda N, et al: Deletion of vascular endothelial growth factor in myeloid cells accelerates tumorigenesis. Nature 2008;456:814-818.

99 Lee S, Chen TT, Barber CL, Jordan MC, Murdock J, et al: Autocrine VEGF signaling is required for vascular homeostasis. Cell 2007;130:691-703.

100 Herbert SP, Huisken J, Kim TN, Feldman ME, Houseman BT, et al: Arterial-venous segregation by selective cell sprouting: an alternative mode of blood vessel formation. Science 2009;326:294-298. 
101 Bry M, Kivela R, Holopainen T, Anisimov A, Tammela $\mathrm{T}$, et al: Vascular endothelial growth factor-B acts as a coronary growth factor in transgenic rats without inducing angiogenesis, vascular leak, or inflammation. Circulation 2010;122:1725-1733.

102 Fischer C, Mazzone M, Jonckx B, Carmeliet P: FLT1 and its ligands VEGFB and PIGF: drug targets for antiangiogenic therapy? Nat Rev Cancer 2008;8:942-956.

103 Schwartz JD, Rowinsky EK, Youssoufian H, Pytowski $\mathrm{B}, \mathrm{Wu} \mathrm{Y}$ : Vascular endothelial growth factor receptor-1 in human cancer: concise review and rationale for development of IMC-18F1 (human antibody targeting vascular endothelial growth factor receptor-1). Cancer 2010;116:1027-1032.

104 Carmeliet P, Ferreira V, Breier G, Pollefeyt S, Kieckens $\mathrm{L}$, et al: Abnormal blood vessel development and lethality in embryos lacking a single VEGF allele. Nature 1996;380:435-439.

105 Kim AD, Stachura DL, Traver D: Cell signaling pathways involved in hematopoietic stem cell specification. Exp Cell Res 2014;329:227-233.

106 Caolo V, Molin DG, Post MJ: Notch regulation of hematopoiesis, endothelial precursor cells, and blood vessel formation: orchestrating the vasculature. Stem Cells Int 2012;2012:805602.
107 Ishige-Wada M, Kwon SM, Eguchi M, Hozumi K, Iwaguro $\mathrm{H}$, et al: Jagged-1 signaling in the bone marrow microenvironment promotes endothelial progenitor cell expansion and commitment of CD133+ human cord blood cells for postnatal vasculogenesis. PLoS One 2016;11:e0166660.

108 Benedito R, Roca C, Sorensen I, Adams S, Gossler A, et al: The notch ligands Dll4 and Jagged1 have opposing effects on angiogenesis. Cell 2009;137:1124-1135.

109 Phng LK, Potente M, Leslie JD, Babbage J, Nyqvist D, et al: Nrarp coordinates endothelial Notch and Wnt signaling to control vessel density in angiogenesis. Dev Cell 2009;16:70-82.

110 Shawber CJ, Kitajewski J: Notch function in the vasculature: insights from zebrafish, mouse and man. Bioessays 2004;26:225-234.

111 Swift MR, Weinstein BM: Arterial-venous specification during development. Circ Res 2009;104:576-588.

112 Harris LG, Pannell LK, Singh S, Samant RS, Shevde LA: Increased vascularity and spontaneous metastasis of breast cancer by hedgehog signaling mediated upregulation of cyr61. Oncogene 2012;31:3370-3380.

113 Bhanot P, Brink M, Samos CH, Hsieh JC, Wang Y, et al: A new member of the frizzled family from Drosophila functions as a Wingless receptor. Nature 1996; $382: 225-230$.
114 Yang-Snyder J, Miller JR, Brown JD, Lai CJ, Moon RT: A frizzled homolog functions in a vertebrate Wnt signaling pathway. Curr Biol 1996;6:1302-1306.

115 Gao ZH, Seeling JM, Hill V, Yochum A, Virshup DM: Casein kinase I phosphorylates and destabilizes the beta-catenin degradation complex. Proc Natl Acad Sci U S A 2002;99:1182-1187.

116 Angers S, Moon RT: Proximal events in Wnt signal transduction. Nat Rev Mol Cell Biol 2009;10:468-477.

117 Dejana E: The role of wnt signaling in physiological and pathological angiogenesis. Circ Res 2010;107:943952.

118 Gill M, Dias S, Hattori K, Rivera ML, Hicklin D, et al: Vascular trauma induces rapid but transient mobilization of VEGFR2(+)AC133(+) endothelial precursor cells. Circ Res 2001;88:167-174.

119 Bhattacharya V, McSweeney PA, Shi Q, Bruno B, Ishida $\mathrm{A}$, et al: Enhanced endothelialization and $\mathrm{mi}$ crovessel formation in polyester grafts seeded with CD34(+) bone marrow cells. Blood 2000;95:581-585.

120 Barr MP, O’Byrne KJ, Al-Sarraf N, Gray SG: VEGFmediated cell survival in non-small-cell lung cancer: implications for epigenetic targeting of VEGF receptors as a therapeutic approach. Epigenomics 2015;7: 897-910. 